\title{
PENINGKATAN PEMAHAMAN MASYARAKAT \\ TENTANG PERLINDUNGAN HUKUM TERHADAP KORBAN TINDAK PIDANA KEKERASAN DALAM RUMAH TANGGA
}

\author{
Haidan Angga Kusumah, R. Eriska Ginalita Dwi Putri, Andi Mulyadi \\ Fakultas Hukum Universitas Muhammadiyah Sukabumi \\ Jl. R. Syamsudin No. 50, Cikole, Kec. Sukabumi, Kota Sukabumi \\ Email: haidananggakusumah@yahoo.co.id, eriska.ginalita@yahoo.com, \\ hammaniandi@gmail.com
}

\begin{abstract}
Domestic violence is a social phenomenon that has lasted a long time in most households in Indonesia. Domestic violence cases dominating against women in Sukabumi. The number of domestic violence cases that occurred in Indonesia is a reflection of the failure of a family to build and maintain a household conditions conducive and comfortable for each family member who took refuge in it. People still think that domestic violence is not a form of crime, is still considered taboo, and is a private matter that should not be to tell. the role performed by the College in providing education to rural communities Padaasih Cisaat about domestic violence and also how the socialization of the Law of the Republic of Indonesia No. 23 Year 2004 concerning the Elimination of Domestic Violence.
\end{abstract}

Keywords: Society, Family, Legal Protection, Domestic Violence

\begin{abstract}
Abstrak
Kekerasan dalam rumah tangga (KDRT) merupakan fenomena sosial yang telah berlangsung lama dalam sebagian rumah tangga di Indonesia. Kasus KDRT mendominasi kasus kasus terhadap perempuan di Kabupaten Sukabumi. Banyaknya kasus KDRT yang terjadi di Indonesia merupakan cerminan gagalnya sebuah keluarga membangun dan membina sebuah kondisi rumah tangga yang kondusif dan nyaman bagi setiap anggota keluarga yang berlindung di dalamnya. Masyarakat masih menganggap bahwa KDRT bukan bentuk kejahatan, masih dianggap tabu, dan merupakan masalah pribadi yang tidak boleh untuk diceritakan. peranan yang dilakukan oleh Perguruan Tinggi dalam memberikan edukasi kepada masyarakat desa Padaasih Kecamatan Cisaat tentang kekerasan dalam rumah tangga dan juga bagaimana sosialisasi Undang-Undang Republik Indonesia No. 23 Tahun 2004 Tentang Penghapusan Kekerasan Rumah Tangga.
\end{abstract}

\section{Kata Kunci: Masyarakat, Keluarga, Perlindungan Hukum, Kekerasan Dalam Rumah Tangga}

\section{A. Pendahuluan}

Kekerasan dalam rumah tangga merupakan fenomena sosial yang telah berlangsung lama dalam sebagian rumah tangga di dunia, termasuk Indonesia. Jika selama ini kejadian tersebut nyaris tidak didengar, hal ini lebih disebabkan adanya anggapan didalam masyarakat bahwa kekerasan dalam rumah tangga merupakan peristiwa yang tabu untuk dibicarakan secara terbuka. 
Kasus kekerasan dalam rumah tangga (KDRT) mendominasi kasus kasus terhadap perempuan di Kabupaten Sukabumi. Hal ini khususnya dialami pasangan suami istri yang dilanda permasalahan di rumah tangganya. Dari data forwa (Forum Wanita) menyebutkan sepanjang tahun 2015 ini tercatat hampir 40 kasus KDRT yang dilaporkan ke lembaga tersebut.

Pemkot Sukabumi menggencarkan sosialisasi pencegahan dan penanganan kekerasan dalam rumah tangga (KDRT). Khususnya, untuk mencegah munculnya korban kekerasan yang dialami perempuan dan anak-anak, upaya ini dengan melibatkan Pusat Pelayanan Terpadu Perlindungan Perempuan dan Anak (P2TP2A) Kota Sukabumi, Babinsa, dan Babinkamtibmas yang ada di lapangan. ${ }^{1}$

Selain itu kiprah Pusat Pelayanan Terpadu Perlindungan Perempuan dan Anak (P2TP2A) di kota sukabumi tidak bisa dipandang sebelah mata. Dalam hal penanganan KDRT yang dilakukannya seperti seorang penyidik atau polisi kerena ada beberapa tahapan yang harus di tempuhnya dalam mmengungkap tabir KDRT

Banyaknya kasus KDRT yang terjadi di Indonesia merupakan cerminan gagalnya sebuah keluarga membangun dan membina sebuah kondisi rumah tangga yang kondusif dan nyaman bagi setiap anggota keluarga yang berlindung di dalamnya. Istilah " keluarga” mengacu kepada rasa aman dan dilindungi, kondisi yang bersifat pribadi dan sebagai tempat berteduh dari tekanan-tekanan dan kesulitan di luar rumah. Angka KDRT dari tahun ke tahun menunjukan peningkatan yang semakin meningkat, upaya pemerintah maupun lembagalembaga sosial untuk menekan angka KDRT. ${ }^{2}$

Saat ini baru sampai tahapan istilah-istilah KDRT menjadi istilah yang cukup akrab digunakan oleh masyarakat, walaupun pemahaman masyarakat mengenai KDRT masih sebatas kekerasan fisik. Sebagian masyarakat masih menganggap bahwa KDRT bukan bentuk kejahatan, masih dianggap tabu, dan merupakan masalah pribadi yang tidak boleh untuk diceritakan. Hal ini lah yang merupakan masalah untuk bisa menghukum para pelaku KDRT.

Banyak orang (entah itu si Pelaku maupun korban) tidak mengerti, apa saja tindakan yang dikategorikan kekerasan dalam rumah tangga (KDRT), seperti yang diatur dalam Undang-Undang No. 23 Tahun 2004 tentang Penghapusan Kekerasan dalam Rumah Tangga $(\mathrm{KDRT}){ }^{3}$

\section{B. Pembahasan}

\section{Kekerasan Dalam Rumah Tangga (Domestic Violence)}

Hukum adalah untuk manusia, maka pelaksanaan hukum atau penegakan hukum harus memberikan manfaat atau kegunaan bagi masyarakat. Masyarakat sangat berkepentingan bahwa dalam pelaksanaan atau penegakan hukum haru diperhatikan.

\footnotetext{
News Republika.co.id, Sukabumi, 24 February 2016, pukul 08.42 WIB

Amalia,E.2000. Kekerasan terhadap Perempuan dalam Keluarga:Analisa Kasus Pada Beberapa Keluarga di Wilayah Ciputat.Jakarta.

Kompas.com, 12 Oktober 2014, pukul 23.00 WIB
} 
Dalam bahasa Inggris, kekerasan diistilahkan dengan "violence". Secara etimology, violence merupakan gabungan dari "vis" yang berarti daya atau kekuatan dan "latus" yang berasal dari kata "ferre" yang berati membawa. Jadi violence adalah tindakan yang membawa kekuatan untuk melakukan paksaan atau tekanan fisik dan non-fisik. Pengertian sempit kekerasan adalah penyerangan fisik terhadap seseorang atau serangan penghancuran perasaan yang sangat keras, kejam, dan ganas.

Kekerasan dalam rumah tangga pada umumnya berhubungan dengan kekerasan berbasis gender (gender based violence). Bentuk kejahatan ini merupakan bentuk diskriminasi yang menghalang-halangi perempuan untuk mendapatkan hak-hak kebebasannya yang setara dengan laki-laki. Jenis tindak kekerasan yang dialami perempuan.

Kekerasan merupakan ungkapan dari suatu "potensi" yang tersimpan pada setiap manusia, yaitu potensi dengan " tendensi" untuk menjelma sebagai tingkah laku yang agresif. Pelaku atau korban KDRT adalah orang yang mempunyai hubungan darah, perkawinan, persusuan, pengasuhan, perwalian dengan suami, dan anak bahkan pembatu rumah tangga yang tinggal dalam sebuah rumah tangga. Tidak semua tindakan KDRT dapat ditangani secara tuntas karena korban sering menutup-nutupi dengan alasan ikatan struktur budaya, agama, dan belum dipahaminya sistem hukum yang berlaku. ${ }^{4}$

Pada umumnya masyarakat menganggap bahwa lingkungan rumah merupakan lingkungan yang aman bagi setiap anggota keluarganya serta orang-orang yang tinggal di dalam rumah tersebut. Tetapi rumah juga rumah dapat menjadi tempat yang berpotensi untuk terjadinya tempat kejahatan.

Berdasarkan Undang-Undang No 23 tahun 2004 tentang PKDRT pada pasal 1 butir 1 menyebutkan bahwa Kekerasan Dalam Rumah Tangga adalah setiap perbuatan terhadap seseorang terutama perempuan, yang berakibat timbulnya kesengsaraan atau penderitaan secara fisik, seksual, psikologis, dan/atau penelantaran rumah tangga termasuk ancaman untuk melakukan perbuatan, pemaksaan, atau perampasan kemerdekaan secara melawan hukum dalam lingkup rumah tangga. Kekeraan dalam rumah tangga juga juga berarti segala bentuk tindak kekerasan yang dilakukan oleh suami terhadap istri yang berakibat menyakiti secara fisik, psikis, seksual dan ekonomi, termasuk ancaman, perampasan kebebasan yang terjadi dalam rumah tangga atau keluarga. Selain itu, hubungan antara suami dan istri diwarnai dengan penyiksaan secara verbal, tidak adanya kehangatan emosional, ketidaksetiaan dan menggunakan kekuasaan untuk mengendalikan istri.

\section{Bentuk-Bentuk Kekerasan Dalam Rumah Tangga}

\section{a. Physical Abuse}

Physical abuse adalah perbuatan yang mengakibatkan rasa sakit, jatuh sakit, atau luka berat (vide pasal 6 UUPKDRT). Kekerasan fisik menunjukan kepada cidera yang ditemukan, bukan karena suatu kecelakaan tetapi cidera tersebut adalah hasil dari pemukulan dengan benda atau beberapa penyerangan. Bentuk-bentuk kekerasan fisik

\footnotetext{
4 Harkrisnowo,H.2000."Hukum Pidana dan Kekerasan Terhadap Perempuan."Dalam A.S.Luhalima(Eds).Pemahaman terhadap Bentuk-bentuk Kekerasan terhadap Perempuan dan Alternatif Pemecahannya. Jakarta:
} 
dapat berupa : dicekoki, dijewer, dicubit, dijambak, dijitak, digigit, dicekik, direndam, disiram, diikat, didorong, dilempar, diseret, ditempeleng, disilet, ditusuk, disabet, digebuk, ditendang, diinjak, dibanting, dibentur, disilet, ditusuk, dibacok, dibusur, dipanah, disundut, disetrika, disetrum, ditembak, berkelahi, dikeroyok, disuruh push up, lari, disuruh jalan dengan lutut

\section{b. Emotional Abuse}

Adalah perbuatan yang mengakibatkan ketakutan, hilangnya rasa percaya diri, hilangnya kemampuan untuk bertindak, rasa tidak berdaya dan / atau penderitaan psikis berat pada seseorang. Kekerasan psikis seperti tidak memperdulikan, mendisriminasi, meneror, mengancam, atau secara terang-terangan menolak anak tersebut. Bentuk-bentuk lain dari tindakan kekerasan mental : dipelototi, digoda, diomeli,dicaci, diludahi, digunduli, diancam, diusir, disetrap, dijemur, dipaksa tulis dan hafal, dipaksa bersihkan wc/ kerja, dipaksa cabut rumput/ kerja

\section{c. Sexual Abuse}

Meliputi pemaksaan hubungan sexual yang dilakukan terhadap orang yang menetap di dalam rumah tangga; pemaksaan hubungan sexual terhadap salah seorang dalam lingkup rumah tangganya dengan orang lain dengan tujuan komersial dan / atau tujuan tertentu (vide pasal 8 UUPKDRT). Kekerasan seksual menunjuk kepada setiap aktivitas seksual, bentuknya dapat berupa penyerangan atau tanpa penyerangan. Kategori penyerangan, menimbulkan penderitaan berupa cacata fisik, kategori penyerangan seksual tanpa penyerangan menderita trauma emosional. Bentuk-bentuk kekerasan seksual : dirayu, dicolek, dipeluk dengan paksa, onani, oral seks, anal seks, diperkosa.

\section{d. Penelantaran Rumah Tangga}

Adalah perbuatan setiap orang yang menelantarkan orang dalam lingkup rumah tangganya, padahal menurut hukum yang berlaku ia wajib memberikan kehidupan, perawatan, atau pendidikan kepada orang tersebut (vide pasal 9 ayat (1) UUPKDRT. Termasuk perbuatan penelantaran rumah tangga adalah setiap perbuatan yang mengakibatkan ketergantungan ekonomi dengan cara membatasi dan/ atau melarang bekerja yang layak di dalam atau di luar rumah tangga sehingga korban berada di bawah kendali orang tersebut ( vide pasal 9 ayat (2) UUPKDRT)

\section{Faktor-Faktor Penyebab}

Di Indonesia, kekerasan dalam rumah tangga sudah banyak dilakukan oleh suami kepada istri, masyarakat sendiri tidak sadar bahwa kekerasan dalam rumah tangga sudah membudaya di Indonesia ada beberapa penyebab terjadinya kekerasan terhadap rumah tangga. Di sini akan dibahas penyebab kekerasan dalam rumah tangga dilihat dari tiga aspek, yaitu aspek ekonomi, aspek sosial-budaya, dan aspek politik ${ }^{5}$

\section{a. Aspek Ekonomi}

5 www.ispirazione.com 
Dilihat dari aspek ekonomi, kekerasan dalam rumah tangga bisa disebabkan oleh

1) Kemiskinan

2) Pendapatan istri lebih besar daripada suami, jika pendapatan istri lebih besar daripada suami, dapat terjadi kecemburuan antara suami dan istri. Sehingga suami merasa disepelekan dan melakukan kekerasan. Ini juga dipengaruhi oleh psikologi

3) Istri terlalu tergantung kepada suami pada suami dalam hal ekonomi, istri yang terlalu tergantung akan membuat suami semena-mena terhadap istrinya, karena dia merasa bahwa istrinya tidak bisa berbuat apa-apa tanpa dia. Sehingga suami bisa berbuat kekerasan kepada dirinya

4) Ekonomi istri dan suami yang mapan membuat mereka mempunyai WIL dan PIL

5) Suami pengangguran dan tidak mau bekerja, suami hanya menunggu hasil kerja dari istri dan merelakan istrinya di eksploitasi demi uang

\section{b. Aspek Sosial Budaya}

Dilihat dari aspek sosial- budaya, kekerasan dalam rumah tangga bisa terjadi karena:

1) Adanya anggapan perempuan hanya sebagai " konco wingking"

2) Persepsi pada masyarakat bahwa kekerasan dalam rumah tangga harus ditutupi, ketika masyarakat memiliki persepsi seperti itu, korban dalam rumah tangga akan menjadi rahasia keluarga sehingga mereka tidak mau melaporkan kepada pihak yang berwenang dan akhirnya kekerasan terus berlanjut

3) Laki-laki dan perempuan tidak diposisikan setara dalam masyarakat

4) Kebiasaan masyarakat mendidik anak laki-laki dengan menumbuhkan keyakinan bahwa anak laki-laki harus kuat, berani dan tidak tolerant

5) Budaya bahwa laki-laki dianggap superior dan perempuan inferior

6) Adanya budaya patriarki, perempuan telah ditanamkan kepatuhan dan pelayanan kepada suami. Suami menekankan hal ini kepada istri sebagai pembenaran atas kekerasan yang dilakukan yang telah dilakukan. Suami memaksa istri untuk melakukan hal-hal yang tidak disukai atau bahkan menyakiti, namun banyak istri yang beranggapan bahwa ini adalah bentuk kepatuhan istri kepada suami sehingga istri tidak menyadari bahwa ini adalah bentuk kekerasan psikologis terhadap mereka.

7) Pengambilan keputusan dalam keluarga yang di dominasi oleh salah satu pihak

8) Tidak adanya demokrasi dalam keluarga

9) Adanya budaya feodal

\section{Peran Perguruan Tinggi Terhadap Kasus-Kasus KDRT}

Dampak kekerasan yang dialami oleh istri dapat menimbulkan akibat secara kejiwaan seperti kecemasan, murung, setres, minder, kehilangan percaya kepada suami, menyalahkan diri sendiri dan sebagainya. Akibat secara fisik seperti memar, patah tulang, cacat fisik, 
ganggungan menstruasi, kerusakan rahim, keguguran, terjangkit penyakit menular, penyakitpenyakit psikomatis bahkan kematian. ${ }^{6}$

Dampak psikologis lainya akibat kekerasan yang berulang dan dilakukan oleh orang yang memiliki hubungan intim dengan korban adalah jatuhnya harga diri dan konsep diri korban (ia akan melihat diri negatif banyak menyalahkan diri) maupun depresi dan bentuk-bentuk gangguan lain sebagai akibat dan bertumpuknya tekanan, kekecewaan dan kemarahan yang tidak dapat diungkapkan.

Penderitaan akibat penganiayaan dalam rumah tangga tidak terbatas pada istri saja, tetapi menimpa pada anak-anak juga. Anak-anak bisa mengalami penganiayaan secara langsung atau merasakan penderitaan akibat menyaksikan penganiayaan yang dialami ibunya, paling tidak setengah dari anak-anak yang hidup di dalam rumah tangga yang didalamnya terjadi kekerasan juga mengalami perlakuan kejam. Sebagian besar diperlakukan kejam secara fisik, sebagian lagi secara emosional maupun seksual.

Kehadiran anak dirumah tidak membuat laki-laki atau suami tidak menganiaya istrinya. Bahkan banyak kasus, lelaki penganiaya memaksa anaknya menyaksikan pemukulan ibunya. Sebagian menggunakan perbuatan itu sebagai cara tambahan untuk menyiksa dan menghina pasangannya. Menyaksikan kekerasan merupakan pengalaman yang sangat traumatis bagi anak-anak, mereka sering kali diam terpaku, ketakutan, dan tidak mampu berbuat sesuatu ketika sang ayah menyiksa ibunya sebagian berusaha menghetikan tindakan sang ayah atau meminta bantuan orang lain.

Menurut data yang terkumpul dari seluruh dunia anak-anak yang sudah besar akhirnya membunuh ayahnya setelah bertahun-tahun tidak bisa membantu ibunya yang diperlakan kejam. Selain terjadi dampak pada istri, bisa juga kekerasan yang terjadi dalam rumah tangga dialami oleh anak. Diantara ciri-ciri anak yang menyaksikan atau mengalami KDRT adalah:
a. Sering gugup
b. Suka menyendiri
c. Cemas
d. Sering ngompol
e. Gelisah
f. Gagap
g. Sering menderita gangguan perut
h. Sakit kepala dan asma
i. Kejam pada binatang
j. Ketika bermain meniru bahasa dan prilaku kejam

6 Saifudien, Sekilas Tentang KDRT Persfektif, dilihat <http://saifudiendjsh.blogspot.co.id/ 2012/02/sekilastentang-kdrt-perspektif-hukum.html>, diakses pada tanggal 4 Januari, 2017 
k. Suka memukul teman.

Kekerasan dalam Rumah Tangga merupakan pelajaran pada anak bahwa kekejaman dalam bentuk penganiayaan adalah bagian yang wajar dari sebuah kehidupan. Anak akan belajar bahwa cara menghadapi tekanan adalah dengan melakukan kekerasan. Menggunakan kekerasan untuk menyelesaikan persoalan anak sesuatu yang biasa dan baik-baik saja. KDRT memberikan pelajaran pada anak laki-laki untuk tidak menghormati kaum.

Negara Republik Indonesia sudah memiliki dasar hukum untuk mengatasi kasus-kasus KDRT. Kurang atau tidak tegasnya penegaka hukum terhadap kasus-kasus KDRT merupakan sesuatu hal yang harus diperbaiki. Penegakan hukum terhadap kasus-kasus KDRT harus didukung oleh seluruh aspek lapisan masyarakat, termasuk di dalamnya adalah perguruan tinggi sebagai suatu institusi yang dapat menyebarkan nilai-nilai kebaikan dan pemahaman tentang penegakan terhadap kasus-kasus KDRT dan juga dari perguruan tinggi tersebut akan dihasilkan sumber daya manusia yang mempunyai kompetensi untuk menangani kasus-kasus KDRT, serta mampu memberikan masukan dan perbaikan tehadap peraturan perundang-undangan dan kebijakan yang berkaitan dengan perlindungan hukum terhadap wanita dan anak yang menjadi korban KDRT.

\section{Penutup}

Berdasarkan pada penjabaran sebagaimana telah dibahas di atas, maka dapat diambil beberapa kesimpulan. Pertama, terdapat beberapa bentuk kekerasan di dalam rumah tangga diantaranya physical abuse, emotional abuse, sexual abuse dan penelantaran rumah tangga. Kedua, terdapat dua faktor penyebab terjadinya kekerasan dalam rumah tangga yaitu faktor ekonomi dan faktor sosial-budaya. Dan ketiga dibutuhkan peran perguruan tinggi dalam mengurangi kemungkinan terjadinya kekedaran dalam rumah tangga. Untuk itu, sudah seharusnya, peguruan tinggi dapat berperan aktif dalam melakukan kegiatan-kegiatan untuk menanamkan nilai-nilai kebaikan dan memberikan penyadaran kepada mayarakat dalam rangka untuk mengurangi kejadian kekerasan dalam rumah tangga yang banyak terjadi.

\section{Daftar Pustaka}

\section{Buku}

Amalia, E., Kekerasan terhadap Perempuan dalam Keluarga:Analisa Kasus Pada Beberapa Keluarga di Wilayah Ciputat, Unpudblished research report PSW IAIN Syarif Hidayatullah, Jakarta, 2000,

Harkrisnowo, H., "Hukum Pidana dan Kekerasan Terhadap Perempuan", Dalam A.S.Luhalima (Eds). Pemahaman terhadap Bentuk-bentuk Kekerasan terhadap Perempuan dan Alternatif Pemecahannya, Kelompok Kerja "Convention Watch", Pusat Kajian Wanita dan Fewleral, Jakarta, 2000. 
Meiyanti, S., Kekerasan terhadap Perempuan dalam Rumah Tangga, Pusat Penelitian Kependudukan UGM dan Ford Foundation, Yogyakarta, 1999.

\section{Jurnal}

Azizah, Siti Nur, Akibat Perceraian Disebabkan Tindak Kekerasan Dalam Rumah Tangga, eprints.undip.ac.id / 17587

\section{Internet}

News Republika.co.id, Sukabumi, 24 February 2016, pukul 08.42 WIB

Kompas.com, 12 Oktober 2014, pukul 23.00 WIB

WWw.ispirazione.com

www.republika.com 